https://helda.helsinki.fi

Teaching: A practical or research-based profession? Teacher candidates' approaches to research-based teacher education

\title{
Puustinen, Mikko
}

2018-08

Puustinen , M , Säntti , J , Koski , A \& Tammi , T 2018 , ' Teaching: A practical or research-based profession? Teacher candidates' approaches to research-based teacher education ' , Teaching and Teacher Education , vol. 74 , pp. 170-179 . https://doi.org/10.1016/j.tate.2018.05.004

http://hdl.handle.net/10138/310809

https://doi.org/10.1016/j.tate.2018.05.004

cc_by_nc_nd

acceptedVersion

Downloaded from Helda, University of Helsinki institutional repository.

This is an electronic reprint of the original article.

This reprint may differ from the original in pagination and typographic detail.

Please cite the original version. 


\title{
Teaching: A practical or research-based profession? Teacher candidates' approaches to research-based teacher education
}

\begin{abstract}
This article analyses teacher training in Finland from the teacher candidate's perspective. The focus is on two key concepts, the Teacher as a Researcher and the Personal Practical Theory, which characterise the agenda of Finnish teacher education. Cluster analysis divided the respondents into five groups, and each cluster had a short textual description. Qualitative data were included in the summary. According to our analysis, the main concepts of the Teacher as a Researcher and the Personal Practice Theory are unclear to teacher candidates and are appreciated differently. Subject teacher candidates in particular, who come from other academic cultures, might consider these concepts educational jargon that have no substance. We also argue that teacher students are not always able to connect the theoretical parts of their studies with practice. These results challenge the claim that Finnish teacher education has resolved the demanding relationship between theory and practice.
\end{abstract}

Keywords: teacher education, cluster grouping, teacher researchers, preservice teachers, personal practical theory, theory-practice relationship 


\section{Introduction}

Finland's education system is internationally well-known as the epitome of organisation in which good learning results and egalitarian objectives meet. Although Finnish learning outcomes in the PISA testing of 15-year-olds have fallen during recent years, Finland is still among the bestperforming countries (Vettenranta et al., 2016). Circumstantial evidence suggests that the decision to train all teachers to Master's level is one reason behind these good learning outcomes (Kansanen, 2014). Finnish teacher education has sometimes been called the model for educating prospective teachers (Kansanen, 2014; Niemi \& Jakku-Sihvonen, 2006; Sahlberg, 2011; Toom et al., 2010; Westbury, Hansén, Kansanen \& Björkvist, 2005).

In earlier papers, we have studied the history of Finnish teacher education (Säntti, Rantala, Salminen \& Hansen, 2014; Säntti \& Salminen, 2015) and the rhetoric behind it, especially the relationship between theory and practice (Puustinen, Säntti \& Salminen, 2015; Säntti, Puustinen \& Salminen, 2018). Based on these studies, we conclude that rhetoric, more than reality, might best serve the interests of Finnish teacher education; especially those of teacher educators and educational scientists. Recent Finnish teacher education research has emphasised its unanimous praise, which has resulted in the research-based paradigm being favoured (for example, Niemi, 2011; Sahlberg, 2011; Tirri, 2014). Therefore, given the exemplary reputation of Finnish education, the system needs to be critically explored. We also need a fresh view with a larger sample than the those used in previous studies.

Finnish teacher education follows a research-based approach. Teacher education studies are structured according to a systematic analysis of education. Educational research and the teaching of student teachers are said to be integrated. Thus, all teaching is based on scientific evidence, and theory-based pedagogical thinking is incorporated into teachers' every action (Jakku-Sihvonen \& Niemi, 2006; Kansanen, 2014; Westbury et al., 2005). The particular starting point of this study was the close reading of teacher education programmes' degree requirements at the X University. We detected two main goals shared by all the teacher programmes: the Teacher as a Researcher (TAR) and the Personal Practical Theory (PPT). The first goal, TAR, is the embodiment of research-based teacher education and is mentioned explicitly several times in the degree requirements. The second goal, PPT, aims to combine the different elements experienced by the students during their education. 
In this article, we study how student teachers experience their teacher education programme from the perspectives of TAR and PPT, both of which represent current teacher education. We divided our research question into three parts: First, based on a survey, we formed typologies to identify the stances of teacher education candidates towards the institutional goals of their education. Then, we analysed how this formulated typology could be explained. Finally, to deepen our analysis and to understand what factors might explain the different attitudes and experiences, we analysed the open-ended questions section of the survey. However, our focus remains clearly on the quantitative data.

Before introducing our data and methods more specifically, we consider theoretical viewpoints and briefly introduce the Finnish teacher education system.

\section{Theoretical considerations}

2.1. Research-based teacher education in Finland in the context of teacher education paradigms

Historically, Finnish teacher education has developed in a unique way. The status of teacher education and that of the teaching profession has systematically risen (Säntti et al., 2018). In the 1960s, the government imposed new theoretical requirements for teacher education, as Finnish society was rapidly changing. At the end of the 1970s, teacher education reached an academic level at which class teachers began to study for the full-scale academic degrees that subject teachers also required. In the wake of this theoretical stance, a new research-oriented teacher emerged. The theoretical views were intensified in the 1990s, when research-based teacher education, the present agenda, was introduced (Kansanen, 2014; Säntti et al., 2018; Toom et al., 2010). This process is seen as the academisation of teacher education (Simola, 2015).

The present-day teacher, even at the elementary and early childhood education level, has received an academic education that includes courses in research methodology and educational theory. Most notably, class teachers are required to write a Master's thesis in education. The subject teacher programme, in which students major in other disciplines, includes a seminar entitled The Teacher as a Researcher. Students carry out their own research on their chosen educational research theme. These studies make tangible the aspiration of Finnish teacher education that teachers achieve full academic status (Kansanen, 2014; Westbury et al., 2005; Tirri, 2015; Toom et al., 2010). 
Admittedly, the Finnish system is only one way of organising teacher education. Various other categorisations delineate how teacher education can be organised according to some leading principle. Zeichner (1983) presented a classic grouping by introducing four alternative paradigms of teacher education: the Behavioristic, Personalistic, Traditional-Craft and Inquiry-oriented paradigms. This categorisation still seems to have explanatory power (Zeichner \& Conklin, 2005; Taylor, 2008) and is actively referred to in current Finnish teacher education (Jyrhämä et al., 2008; Krokfors et al., 2011).

Next, we try to define Finnish teacher education according to its conceptual orientation (Zeichner \& Conklin, 2005). For Zeichner, this conceptual orientation is a 'paradigm' that represents a 'matrix of beliefs and assumptions' behind different teacher education programmes. Feiman-Nemser (1990) in turn consider these various orientations and paradigms to reflect 'a cluster of ideas about the goals of teacher preparation and the means for achieving them'. When Finnish teacher education is represented as research-based, this orientation is called an 'organising theme' (Krokfors et al., 2011). Nevertheless, whether a teacher education programme is understood in terms of a paradigm, orientation, leading principle or organising theme, it should reflect what that particular teacher education programme envisages and aims to achieve (Krokfors, 2011; Zeichner \& Conklin, 2005).

By juxtaposing various researchers' different categorisations, we can find similarities. For example, Zeichner's personalistic (1983) and Feiman-Nemser's personal orientations (1990) represent a teacher education paradigm in which personal and developmental matters are central. The focus of these models is student teachers' growth (through nurturing) as a teacher. Taylor (2008) uses the term 'enabling students"' individual growth as teachers when representing a similar personalistic view.

The traditional craft teacher education paradigm sees the educator as a competent craftsperson, and regards teaching as a craft, in which the pedagogical knowledge (perhaps acquired by trial and error) of experienced educators is appreciated (Feiman-Nemser, 1990; Zeichner, 1983). This seems to resemble Moore's (2004) training discourse, which profiles teachers as 'competent craft persons'. Taylor (2008) also acknowledges this approach with the term, 'cascading expertise', in which information and expertise are transmitted from experienced teachers to novices. 
The current agenda of Finnish teacher education corresponds to Zeichner's (1983) inquiry-oriented paradigm and Feiman-Nemser's (1990) technological orientation. In Zeichner's view, teachers are prepared to analyse their actions and the ensuing consequences. Although Feiman-Nemser's technological orientation sounds rather strange, its agenda includes the idea that knowledge is 'derived from the scientific study of teaching' and uses 'research-based principles and practices', which are actually a more accurate depiction of Finnish teacher education than that of Zeichner.

In more recent categorisations, the Finnish teacher education paradigm appreciates Moore's (2004) 'teacher as a reflective practitioner'. This reflective educational practitioner is not a mere recipient of professional knowledge produced by an educational scientist. Rather, the teacher is an autonomous actor who also participates actively in knowledge production. Taylor's (2008) concept of 'students as teachers and learners' also accurately reflects the basic idea of Finnish teacher education, in which students are expected to think critically and develop their own thinking. This resembles the concept of PPT, which is one element of research-based teacher education.

In 1981, Elbaz (1981) launched the term Practical Knowledge, which includes practical assumptions, rules of practices and images. These, in turn, are said to lie behind the decisions and actions that a teacher chooses to take. Korthagen (2011) speaks about PPT as a cognitive network, made up of concepts, characteristics and principles. Levin and He (2008) also use the term PPT, but lists a few analogous labels: Personal Practical Knowledge, the Practical Theory, Practical Reasoning, Practical Philosophy, the Theory of Action, and Schema. These terms refer to the interaction between the knowledge, beliefs and practices in the minds of teacher candidates (and later when they are teachers). These matters in turn originate from life history as a family member and pupil at school and observations made in field experiences in teacher education and academic courses (Levin \& He, 2008).

Finnish views of PPT share the above-mentioned definitions (Jyrhämä et al., 2008; Stenberg, Karlsson, Pitkäniemi \& Maaranen, 2014; Westbury et al., 2005). Thus, in constructing PPT, the teacher students use their everyday teaching experiences (intuitive reasons) combined with theoretical elements familiar to educational science (rational reasons), as well as their personal experiences. Nevertheless, it seems that the Finnish view of PPT emphasises academic studies and scientific elements when a teacher candidate constitutes their PPT. This is quite understandable in the context of research-based discourse. 
2.2. The need to re-estimate Finnish teacher education

There seems to be no debate about the fact that Finnish teacher education follows a research-based orientation (Zeichner \& Conklin, 2005) or paradigm (Zeichner, 1983). It is repeatedly reproduced in various Finnish teacher education studies and policy documents (Säntti et al., 2017). However, this orientation is rather problematic from both theoretical and practical perspectives. Theoretically, it includes various elements and concepts. The relationships between the TAR and PPT concepts are complicated and unclear (Krokfors et al., 2011).

TAR is one concept of a research-based approach, but at the same time it is a kind of incarnation of a research-based agenda that a teacher should embody. When a research-based agenda is truly functional, teachers are research-oriented in their actual educational work. The aim of teacher education is to produce teachers who will and can also conduct research. Teacher students are expected to study research methodology and become acquainted with educational theory. The other cornerstone of the research-based approach orientation is PPT. This can be seen as a theoretical collection owned by every individual teacher (as a researcher). Thus, the organising theme (research-based paradigm) is expected to be appreciated by educational actors (TAR) who in turn have their own theoretical mindset (PPT) that enables them to make autonomous pedagogical judgements as teachers.

Nevertheless, from the perspective of teachers' daily work, it is somewhat unclear what a researchbased agenda really means. In some views, the idea of Finnish teacher education is not to produce educational researchers or teacher-researchers (Kansanen, 2014; Krokfors et al., 2011; Toom et al., 2010) whereas other views expect teachers to conduct small-scale studies in their classrooms (Ministry of Education, 2007) or at least have the capacity to do so (Niemi \& Jakku-Sihvonen, 2006; Kansanen, 2014; Westbury \& et al., 2005). This inconsistency may be due to the lack of proper counterparts for the verbs to 'inquire' and to 'research' in the Finnish language. In some texts, the words are used synonymously (Jyrhämä \& Maaranen, 2012), but we see a difference: 'to inquire' is to have an investigative stance, whereas 'to research' includes the subsequent publication of results for a wider public (Munthe \& Rogne, 2015).

Another reason for inaccuracy may be rhetoric: it can be useful to highlight the research orientation for academia and to portray teachers as professionals with a scientific education (for example doctors or lawyers). Thus, the research-based agenda corresponds to teacher educators' interests. At 
the same time, it would be unconvincing to describe the teaching staff at schools as researchers. Controversial views whether a teacher is a genuine researcher have produced the idea of 'the halfeducated researcher', who merely 'tinkers' with research (Säntti et al., 2017).

When teacher candidates or teachers are asked about their opinion of the Finnish research-based agenda, the responses are contradictory. Some studies have found that student teachers appreciate the research-based approach (Byman et al., 2009; Jyrhämä et al., 2008), whereas others have concluded that the school teachers have adopted research orientation (Jyrhämä \& Maaranen, 2012). One study found that teacher graduates welcomed a research-oriented education and the idea of the reflective teacher, which echoes the tenets of the research-based agenda (Niemi \& Tirri, 1997). Such studies present the chosen agenda in a favourable light.

Other papers represent different views: when recently graduated teachers evaluated their education, they criticised it for being too rational and research-based, and alien to teachers' everyday work (Blomberg, 2008). In another study, novice teachers noted that research skills were not significant in helping them secure employment (Rautapuro, Tuomisto \& Puhakka, 2011). Thus, some studies (Autio, 2015; Kinos, Saari, Lindén \& Värri, 2015) have asked whether the faith in methodological studies and the research-based agenda is relevant when dealing with complicated yet practical school issues. The chosen strategy has gained ground from alternative approaches. This 'culture of method' has meant that means and tools (such as research methodology) are preferred over the values, norms and goals in courses that deal with societal, philosophical or ethical questions, for example.

\section{Data and methods}

\subsection{Data}

The data for this study consist of a survey that was conducted in 2014-2015. The survey was completed by 905 teacher candidates who studied pedagogy at the Department of Teacher Education at the X University. The data were collected during a compulsory course called Social, Historical and Philosophical Foundations of Education. Thus, practically all the students who took the course during this period were included in our data. We briefly outlined the idea of our research in a proposal. However, we did not explain the key concepts, TAR and PPT, to the respondents, because we wanted to determine how well they recognised and understood them. 
The questionnaire contained a background information section, general questions about the education, and two sections of questions crafted around the institutional goals, TAR and PPT. ${ }^{1}$ In addition to age and gender, the background section of the questionnaire elicited the respondents' teaching experience and academic degree. These areas arose from earlier research that suggested they could explain some of the respondents' views. As Table 1 shows, the sections focusing on TAR (Q4.1-4) and PPT (Q5.1-4) were constructed in a similar way. The first question targeted the familiarity of the institutional goal in question and the second sought to determine whether the education had rendered this goal tangible. Third, we inquired about the respondents' views on whether the goal was well-grounded in teacher education, and in the last subsection we asked whether they appreciated this goal in the working context of teachers. Every question included these four subsections. Cronbach's alpha value 0.706 implies good internal consistency and reliability of the instrument (TAR $\alpha=0.65$, PPT $\alpha=0.748$ ). The scale consisted of five response options, of which 1 meant strong disagreement and 5 meant strong approval of our proposition. Choosing response option 3 meant the respondent was neutral or uncertain.

Each section of the survey offered the opportunity to provide written clarifications and comments. The students had about 15 minutes to complete the questionnaire and answer the open-ended questions. The qualitative data from the TAR and PPT sections of questionnaire consisted of 581 comments. In total, 426 respondents, i.e., 47 per cent answered at least one of the open-ended questions.

Our focus is on class teachers and subject teachers. In Finland, class teachers teach the first six grades of elementary school and education is their major study subject. Subject teachers study their teaching subject as their major (mathematics, history, etc.) and are oriented to teach in secondary and upper-elementary schools. Class teachers undertake Master's level studies in a faculty of education, whereas subject teacher candidates study Master's level studies in their own department. Both class and subject teachers must undertake pedagogical studies to become certified teachers. Both groups study from five to six years before graduating and accepting teaching positions.

At the X University, teachers' pedagogical studies consist of numerous individual courses amounting to a total of 60 ECTS credits. Studies consist of about 20 separate courses, from

\footnotetext{
${ }^{1}$ The section focusing on TAR is coded Q4.1 etc. and PPT Q5.1 etc. This paper does not cover the general questions about teacher education at the $\mathrm{X}$ University.
} 
educational psychology and subject didactics to the social, historical and philosophical aspects of education. We stress that in this study, we examine the overall objectives set for Teacher Education at the X University, and not the specific learning goals that students are expected to achieve, or the activities that take place in different courses. Clarifying how this general agenda is implemented in the courses would require a separate study.

Most of the respondents $(n=749)$ were subject teacher candidates. Generally, subject teacher students complete their pedagogical studies in one academic year and may take part in pedagogical studies at any stage of their major studies, except for home economics and textiles teacher students. These students were in their second year of study when they took part in the survey. Class teacher candidates study either educational science $(n=129)$ or educational psychology $(n=27)$ as their major. They were mainly at the beginning of their second year of study when they took part in the survey. ${ }^{2}$ Because of these variations, our data contain respondents whose experience of teachers' pedagogical studies was heterogeneous. Appendix A shows the background information of our respondents.

\subsection{Methods}

From our data, we identified five student profiles using cluster analysis. We used K-means cluster analysis to generate un-nested profiles of the student teachers who participated in the study. Due to iteration, cluster centres were formed so that the answers of the respondents in the same cluster were more similar to each other than to those in other clusters (Tan, Steinbach, \& Kumar, 2005). The similarities and differences were then explored through ANOVA post hoc procedures, using the Tukey correction method.

To determine what might have generated the different profiles, we formed two categories discipline and phase of studies - which we used to combine the background variables. Our hypothesis was that the students' discipline would be significant. The disciplines were organised into seven categories: mathematics and science; social sciences and history; arts; languages; home economics and textiles teacher education; pedagogy; and miscellaneous. These categories do not follow the division of faculties at the X University, although the categories of pedagogy and home

\footnotetext{
${ }^{2}$ Subject teachers are coded 1-749 and class teachers 1001-1157.
} 
economics and textiles teacher education consisted of students who were only studying their major in the Faculty of Behavioural Sciences.

Earlier research suggests that integrating academic cultures may be a challenge for subject teacher education in the Finnish context (Ylijoki, 1998; Virta, Kaartinen \& Eloranta, 2001). Subject teacher candidates first study for several years in their own faculty, before spending one academic year undertaking their pedagogical studies. When subject teacher candidates begin their pedagogical studies, they are already well socialised within their own discipline and its academic culture (Becher \& Trowler, 2001), which may conflict with the culture of the Department of Teacher Education. Thus, we explored whether the phase of the studies had any significance for the respondents' ratings. These categories - early, middle and final stage - are based on the sum of the students' credit points.

Our analysis focused on quantitative data. However, as we wanted to produce more meaningful interpretations of our results, we turned to open-ended questions. We sorted the qualitative data in accordance with the formulated clusters. The answers to the open-ended questions were fairly equally distributed over the clusters. Inside every cluster, the qualitative data were coded into three categories: favourable, negative and neutral. At this point of the analytical process, we discussed the coding results in detail to ensure that we all shared the same interpretation (see for example, Stes \& Van Petegem, 2014). Finally, we created textual descriptions of every cluster and formed a motto to characterise each cluster. We used quotations to provide interpretations of the profiles.

We were also interested in the factors that might explain the teacher candidates' stances towards these two specific goals of teacher education. To do this, we analysed the open-ended questions separately from the profiles, and grouped the answers under different themes.

\section{Results}

4.1 Teacher candidates' orientation towards the institutional goals of teacher education: five profiles

The results showed significant differences between the clusters in terms of all the measured variables $(p<0.001)$. The analyses of the mean ratings and standard deviations from ANOVA procedures also showed support for a five-cluster solution. Table 1 summarises the cluster means, standard deviations and mean ratings of all the data. 
Table 1 and Figure 1 here

Table 1

Cluster means, standard deviations, general mean scores

Note: This table displays the cluster means and standard deviations of each cluster and mean ratings of all the data.

Note: The numbers $1-8$ at the bottom of the graph indicate the questions introduced in Table 1 $\left(\mathrm{Q} 4 \_1=1, \mathrm{Q} 5 \_1=5\right)$. The numerical scale on the left of the graph displays the mean ratings.

Fig. 1

Visual representation of clusters

The results of the post-hoc procedures indicated the preservice teachers' differing orientations towards the institutional goals of TAR and PPT. As regards the teacher candidates' ratings of the recognisability of the agenda for TAR as an institutional goal, the results showed significant differences between Cluster 5 and the other clusters $(p<0.001)$, and between Clusters 1 and 2 ( $p<$ $0.001), 1$ and $3(p=0.011)$, and 2 and $4(p=0.022)$. We also found significant differences between the ratings of the competencies provided by teacher education for working as a teacher-researcher. Clusters 1 and 5 differed significantly from the other clusters $(p<0.001)$. However, we found no significant differences between Clusters 2, 3 and 4. The differences between the cluster ratings regarding the justification of the aim were significant $(p<0.001$; between Clusters 3 and $4 p=$ 0.013) between all clusters except for Clusters 2 and 5, between which we found no significant difference. The ratings of work life relevance followed a similar tendency $(p<0.001$, no significant difference between Clusters 2 and 5).

As regards the teacher candidates' ratings of the recognisability of the agenda of PPT as an institutional goal, Clusters 1 and 3 differed significantly from the other clusters $(p<0.001)$. We found no significant differences between Clusters 2, 4 and 5. Their ratings of competencies provided by teacher education for PPT, Clusters 4 and 5, showed similarities, but significant differences were observed between all the other clusters $(p<0.001$; between Clusters 2 and $5 p=$ 
0.031). In the ratings of the importance of PPT as part of teacher education, both Cluster 1 and Cluster 3 differed significantly from the other clusters $(p<0.001)$. The ratings of Clusters 2,4 and 5 showed no significant differences. A post-hoc test on the ratings of the relevance of PPT for the teaching profession showed significant differences between Cluster 1 and the other clusters, and between Cluster 3 and the other clusters, while tests for ratings in Clusters 2, 4 and 5 implied similarities.

\subsubsection{Cluster 1: Teacher training does not answer to our needs to construct PPT}

Participants in Cluster $1(n=103)$ rated the relevance of PPT as a goal of teacher education and its relevance to work life as high. At the same time, they seemed to remain mostly sceptical regarding how teacher education is currently organised. Thus, we described this cluster as: 'Teacher training does not answer to our need to construct PPT before moving to the teaching profession, although it would be of high priority'.

It is noteworthy that the respondents' ratings of the aim of TAR also indicated a sceptical orientation. While they recognised the aim to produce teacher-researchers, their ratings expressed scepticism towards the relevance of this aim for the teaching profession. Thirty-four students wrote comments in the open-ended questions regarding this variable. Most made critical observations of the justification of TAR. For example: 'If the teacher as a researcher means a teacher who studies education or who considers teaching to be a scientific endeavour, the ideal is poorly grounded. Practical everyday school work is something completely different (Respondent 272, biology)'.

All 18 of the critical comments concerning PPT suggested that the education does not support the construction of PPT. In this cluster, no directly critical comments were made towards PPT itself.

\subsubsection{Cluster 2: Why study research for the teaching profession?}

Participants' ratings in Cluster $2(\mathrm{n}=179)$, like those in Cluster 3, indicated that they fully recognised the institutional aim of TAR. As in Clusters 3 and 4, their ratings suggest that they consider teacher education to have succeeded rather well in providing the relevant skills. However, like the Cluster 5 participants, they questioned whether research skills were central to teacher education or to later teaching practice. 
We found a somewhat similar, though more subtle tendency when interpreting the ratings of PPT. However, participants in Cluster 2 were less sure of the recognisability of the aim to formulate PPT during their education. Like the participants in Clusters 4 and 5, their ratings indicated that they remained relatively unsure of whether PPT can be considered central to teacher education or to their forthcoming profession. As they gave the working life relevance of both aims the lowest rating among our test group, our analysis allows us to formulate the following motto for Cluster 2: 'Why do we have to study to become teacher-researchers, as the teaching profession is not necessarily based on research?'

The responses to the open-ended questions suggest that the participants in Cluster 2 were quite critical of the TAR agenda. The respondents provided 51 answers that can be interpreted as critique. Our interpretation of the open-ended questions is that the respondents did not agree with the link between research-based education and a teacher's daily work: 'If there is no time for research in a teacher's work, concentrating on research this much in teacher education is rather pointless (Respondent 491, mathematics)'.

Most students in this Cluster were unfamiliar with the concept of PPT (48/64 of open-ended answers). One reason for this could be that these students had not yet been introduced to the concept during their studies. Another reason might be that they considered PPT to be something that only develops through teaching experience in schools and thus cannot be developed before starting work as a qualified teacher.

\subsubsection{Cluster 3: Both goals are reasonable, but PPT is the most important}

Our interpretation of the ratings in Cluster $3(n=262)$ is that participants recognised both of the institutional goals explored in this research relatively well. In this regard, they shared similarities with Cluster 4. Like Clusters 2 and 4, the ratings in Cluster 3 suggest that the participants thought that teacher education had succeeded in providing the relevant competencies for acting as teacherresearchers. Regarding the relevance of TAR for teacher education and work life, they answered more critically than the Cluster 4 participants, but less critically than the respondents in the other clusters.

Cluster 3 respondents were the most content with the aim to construct PPT. The ratings suggest that even more emphasis could be placed on PPT than currently. They valued it highly in terms of its 
relevance for teacher education and the profession. We describe Cluster 3 as follows: 'The idea of both TAR and PPT are acceptable, but the studies should focus more on PPT because it is more important in teachers' daily work.'

Once again, the open-ended question section offered a more detailed view. Some respondents did not believe that a teacher's work was based on research: 'In everyday school work, routines and control of pupil groups seem to be more important than conducting research' (Respondent 167, French philology). Nevertheless, others felt that research-based education could be one solution for professional development: 'In my opinion, teachers have to continuously maintain and update their professional knowledge and skills with the help of educational research' (Respondent 1055, class teacher).

Concerning PPT, both the numeric data and the open-ended questions indicated consistency and a positive stand. Perhaps because the respondents in this cluster felt that PPT was so important, they needed a broader example of how to construct it. Based on the open-ended questions, teacher training, and especially teaching practice, does not support students in the process of constructing PPT: "The emphasis is on the verb "strive" and I refer to my previous comment about practical tools [respondent required more concrete tools]. Theory does not help in the field if no support for applying theory in class situations is provided' (Respondent 643, Finnish language ).

\subsubsection{Cluster 4: Primary aim: The teacher as a researcher}

Participants' ratings in Cluster $4(n=205)$ indicated that they were well aware of the aim of TAR. Like those in Clusters 2 and 3, their ratings suggested that they felt that they had been provided with the relevant skills, yet they seemed to hope for more emphasis on TAR in their studies as they considered it important for their upcoming profession. Therefore, we described their point of view as follows: 'The idea of TAR materialises in the studies and I will continue to follow it in my own work as teacher".

Although the students in this cluster seemed to have a positive stance towards the idea of TAR, some of their comments also suggested a somewhat critical attitude. First, the respondents pointed out that while teachers should be able to develop their own practices, they do not see teachers carrying out academic research. This brings into question the special feature of the Finnish language mentioned above regarding the interpretations of the word 'research' in Finnish. In English, they 
could express themselves by saying they were ready to accept small inquiries in the classroom, but not full-scale (academic) research. Second, while the respondents recognised and accepted the objective of TAR, they were quite critical of the way in which it was implemented in their studies. One respondent noted, 'They keep talking about inquiry-based learning but they do not show us how it is done in practice' (Respondent 204, mathematics).

Regarding PPT, the participants' ratings in Cluster 4 were similar to those in Clusters 2 and 5. They rated the relevance of PPT as the objective of the studies and its working life relevance more critically than the participants in Clusters 1 and 3. However, this might be because they were unfamiliar with the concept, as is suggested by their responses to the open-ended questions. More than half (47/74) of the students wrote that they were not familiar with the concept. Some critical attitudes were also evident. Here, in the classic challenge of teacher education, the theory and practice dilemma was obvious: 'What does PPT mean? If it means the connection between theory and practice, this would be very important in teacher's work but in teacher education, too often theory comes first and the link to practice is forgotten' (Respondent 1081, class teacher).

\subsubsection{Cluster 5: A teacher is a teacher, not a researcher}

The ratings of the recognition of TAR's ideal were the lowest in Cluster $5(n=156)$. This may suggest that the respondents did not recognise the TAR ideal or thought they had not been given relevant competencies for practising it. Their ratings of its relevance to teacher education and the profession may be interpreted as sceptical. Although the Cluster 5 ratings were somewhat similar to those in Cluster 2, they differed from them in that the participants did not feel that they had been given the relevant competencies. Thus, based on our analysis, we summarise the responses of these participants as follows: 'A teacher is a teacher, not a researcher'.

The open-ended comments suggested that the students believed that school reality and a teacher's practical work did not support the TAR approach to teaching: 'The inconsistency between educational research and the school reality is substantial' (Respondent 35, home economics). The respondents also felt that their education did not prepare them to work as a teacher-researcher.

The Cluster 5 respondents were not sure whether there was an agenda for PTT. Their ratings may be interpreted as manifesting doubt regarding the competencies they have obtained. They gave a lower rating to the relevance of this aim for teacher education and profession. We interpret that the 
respondents were somehow unclear about the concept of PPT, as it seemed unfamiliar to many of those belonging to this cluster (44/60). As in Clusters 2 and 4, some participants may also have felt that PPT is something that develops mainly in a teacher's practical work, not during the initial teacher training.

\subsection{Explaining the formulated typology}

The five clusters generated show variance across the teacher candidates' attitudes towards the institutional goals of TAR and PPT, their fulfilment and their relevance to both teacher education and the teaching profession in contemporary schools. In this section, we discuss the potential explanations for the differences between the clusters.

When analysing whether the respondents' disciplines guided their view, we found no significant differences in the systematic results of the questions focusing on TAR. However, in each of the four questions focusing on PPT, the ratings given by class teacher candidates were significantly higher than those given by the social sciences group (Q5.1. $p<0.001, \mathrm{Q} 5.2 . p=0.019, \mathrm{Q} 5.3 . p=0.006$, Q5.4. $p=0.04)$. Furthermore, in the first three questions, the ratings provided by the class teacher candidates were significantly higher than those given by the group associated with languages (Q5.1. $p<0.001$, Q5.2. $p<0.001$, Q5.3. $p=0.01)$.

Students who had reached the middle $(p=0.002)$ and final $(p=0.008)$ phases of their studies had significantly stronger opinions than the respondents in the early phase regarding whether teacher training aims to promote TAR (Q4.1). Despite this, the respondents who were at the final stage of their studies believed the least that the teaching profession was based on the idea of TAR (Q4.4, between the early and final phases $p=0.007$ ). This response may be because in the latter phases of their studies the students had participated in teaching practice. During early experiences in front of pupils, the agenda of TAR might feel distant. Students might have also felt that experiences from teaching practice did not integrate with the theoretical sides of teacher education.

The respondents in their early study phase more strongly felt that their education aimed to promote PPT (Q5.1) than the students who were in the middle phase $(p=0.038)$ or final $(p=0.002)$. This discrepancy between the results may be explained by the structure of pedagogical studies and the lack of clarity in the PPT concept. It may also partly be explained by the distribution of class and 
subject teachers. In our data, class teacher candidates were more often in the early phase of their studies than the subject teacher candidates.

Although the background variables may explain some of the results, they do not explicitly explain the differences between clusters. The variables of age, gender, degree and teaching experience proved insignificant. With the exception of Clusters 2 and 3, the distribution of students was normal. Cluster 2 had more social science students and fewer students belonging to the pedagogy group, and the difference was significant. Cluster 3 had more class, home economics and textiles teacher students, but this difference was not significant. The academic background of the students in Clusters 2 and 3 seemed to fit our presupposition that students who always study in the Faculty of Education may be more eager to accept the agenda of teacher training. They are more 'exposed' to the agenda, since they take all their courses at the Faculty of Education, whereas subject teachers mainly study in their own faculties. Cluster 2 (more subject teacher candidates) was more critical of PPT than Cluster 3 (more class, home economics and textiles teacher candidates). Interestingly, in Cluster 1, which was quite critical of PPT, there were fewer respondents from the education group than we expected. In Cluster 2, fewer respondents were in the early phase of their studies, while the Cluster 4 respondents were more often in the early or middle phases of their studies. However, neither of these differences was significant.

One critical observation concerning our interpretation of PPT was the high percentage of students who were not familiar with the concept. Based on the open-ended question responses, twenty per cent of subject teacher candidates and 11 per cent of class teacher candidates were unfamiliar with the concept of PPT. It is uncertain how many did not provide answers to the numerical questions about whether they were familiar with the idea behind the PPT. Therefore, in the first part of our analysis, when we were operating with only numerical data, there was considerable opportunity for bias when interpreting the cluster values as neutrality or approval. The students recognised the TAR agenda better than PPT; therefore, they were able to give more informed answers.

\subsection{Teacher candidates' descriptions of their orientation and attitudes towards the institutional goals of teacher education}

According to the quantitative ratings, the respondents seemed to be quite satisfied with the education they had received. However, when we looked at the responses to the open-ended questions, the respondents seemed to be much more critical of their education and its goals. Even 
though the open-ended section answers were fairly evenly distributed across the clusters, the comments were mostly negative or critical regardless of which cluster they come from. Of course, this could be due to the simple fact that those who were not satisfied were more eager to record their complaints and critique when given the opportunity.

The open-ended section comments enabled us to better understand what might underlie the respondents' numerical answers. In these comments, three themes arose frequently: 1) in the school reality, teaching is a practical profession; 2) teacher education is theoretical, but learning to teach is learning by doing and 3 ) teacher education is not consistent.

First, when commenting on school reality, the respondents described teaching as a practical occupation. Therefore, many felt that one cannot be both a teacher and a researcher. Teaching was perceived as being so time-consuming that teachers simply do not have time to conduct research or follow up the latest research findings. Furthermore, several comments questioned the whole concept of the teacher-researcher: it was far from clear to these student teachers why the TAR concept was emphasised in their studies. The student teachers wanted a more practical approach to teaching.

Second, for many respondents, teacher education was too theoretical. They yearned for more 'learning by doing'. Because teaching was thought to primarily require practical skills and understanding of the school reality, the student teachers recognised the limits of what researchbased teacher education could offer. The comments about PPT contained numerous statements about the divide between theory and practice. While many of the students recognised the importance of constructing their own PPT, they did not expect it to occur during their initial teacher education. In other words, many of the students valued personal teaching experience over theoretical studies. It is worth mentioning that if students do not recognise the substance or meaning of PPT, then it is almost impossible to construct it or reflect any signs of PPT. In this sense, the studies might not be able to deconstruct the division between theory and practice.

The third theme is the internal inconsistency of teacher education. Even though students recognised the goals of research-based teacher education, they thought that the agenda was unrecognisable throughout the study programme. According to the students, some courses and lecturers emphasised the ideas of TAR and the importance of PPT, while others hardly mentioned them. 
In summary, our analysis revealed significant differences between respondents: TAR and PPT were appreciated differently. The picture our data produced is ambiguous. It seems that some students saw these ideas as central to teacher education, others saw that they did not belong to either teacher education or teachers' work, and a few saw these ideas as being relevant to education but not to teachers' work. Finally, some accepted only one of teacher education's tenets, and others did not understand the given concepts.

The results support our hypothesis that class teacher and subject teacher candidates have different attitudes and approaches. However, most of the results were based on other factors that cannot be completely reached with quantitative methods. We described the respondents' attitudes more specifically with qualitative data. Nonetheless, the picture could be more accurate.

\section{Discussion}

5.1. Are unclear key concepts blurring the challenges of teacher education?

Based on our study, it seems that students mainly have a positive attitude towards Finnish teacher education's agenda, but that some also criticise it. In the 1990s, a considerable number of theoretical studies were included in the curricula of Finnish teacher education departments and the number of practically-oriented studies decreased (Säntti et al., 2014; Puustinen, 2012). Hence, it is tempting to conclude that students yearn for more practical teacher education. However, this would not be a satisfactory conclusion, as our study probed whether student teachers approved of only the current agenda, not the possible alternatives. Yet, our aim to analyse more carefully whether the claimed strong relationship between theory and practice in Finnish teacher education may be more of a rhetorical alteration than a real change in educational practice, was fulfilled.

Our findings are in line with those of earlier studies, which have shown students to value practical orientation more highly than the theoretical elements of their studies (Allen, 2009; Sjølie, 2014) and that teacher candidates do not always see the relevance of theory (Korthagen, 2001; Krokfors et al., 2010; Loughran, 2006). Sjølie (2014) analysed the beliefs and thoughts of Norwegian student teachers. The conclusion was that the concept of theory seems to have a wide range of meaning, the role of theory is understood in many ways, and the theoretical elements of education are considered to be too general (see also, Darling-Hammond, 2010). Sjølie raises the question of whether 
preservice teachers are satisfied with the content of teacher education or whether the pedagogy of teacher education is the problem.

Based on our analyses, the concept of PPT is somewhat unclear to student teachers. The pedagogical practices in teacher education may explain this to some extent, as may the students' attitudes. It may also be the case that, although PPT is a useful analytical tool and an encompassing concept for educational researchers when studying teachers' or student teachers' pedagogical thinking, for these educational actors themselves, it may just be some empty concept that may not be very useful when planning, interacting or reflecting on tuition in real school life circumstances. All the same, we stress that it would be a misleading simplification to conclude that the agenda itself is acceptable to students; implementing TAR and PPT in the teacher education programme may indeed be problematic.

Finnish teacher education has developed from a practice-oriented and (nationalistically) normative model to the present-day research-based system (Säntti \& Salminen, 2015). Each stage in this process can be connected to one or more paradigms or orientations of teacher education. Because of rather rapid development, pedagogical studies may consist of courses representing different historical layers and paradigms transmitted from earlier decades. Even though the agenda of Finnish teacher education is solid and shared by all Finnish teacher education departments (Rantala et al., 2013), we assume that everyday practices and even courses taught by different teacher educators can interweave many paradigms, and produce tensions as well as open new pathways between different perspectives. Furthermore, for subject teacher candidates, these sometimes contradictory views are connected to clashes between academic cultures. All of this creates a view of teacher education as a meeting place of cultures, paradigms and historical layers and helps to explain why our study produced such a multi-dimensional picture of student teachers' views.

Our conclusion differs from earlier findings concerning teacher education at the X University. In previous studies, teacher candidates have appreciated the research-based approach (Byman et al., 2009; Jyrhämä et al., 2008; Kansanen, 2014; Jyrhämä \& Maaranen, 2012; Krokfors et al., 2011; Munthe \& Rogne, 2015; Westbury et al., 2005). Research-based thinking is presented as the allencompassing agenda of the current Finnish teacher education model, which also has exact presumptions regarding teachers' work. PPT, on the other hand, is seen as a kind of melting pot, the reduction of everything that has had an effect on the teacher or student teacher. When reading about Finnish teacher education, one immediately sees that these theoretical ingredients actually work 
together. This relationship is not presented as an ideal or objective, but rather as the prevailing reality in Finnish teacher education. Our findings challenge such a static idea.

These sometimes conflicting roles in teacher education indicate a need to define research-based teacher education. Earlier we have found that policy documents governing teacher education do not clarify central concepts such as theory or research, although they are repeatedly used in argumentation (Säntti et al., 2018). One can interpret this lack of precision as a rhetorical tactic to make it more difficult to challenge this argumentation. In fact, teacher educators may find these concepts a mantra to be repeated (Krokfors et al., 2011).

For teacher candidates, policy level is not necessarily visible or important. However, as our results indicate, ambiguity regarding key concepts can reflect on how teacher candidates embrace the theoretical parts of their education and further on their actions as future teachers. This also contradicts the idea that teacher education should be clear about its aims and ideas (Krokfors et al., 2011; Zeichner \& Conklin, 2005). For many of the participants in our survey, the role of research in teacher education seemed rather unclear, and some even refused to accept it as a meaningful part of teacher education. The consequences of this result should be examined in further studies. Teacher candidates' different approaches indicate that some teachers do not understand or agree with the role of research in teacher education or teachers' work. Further, this may indicate that teacher candidates have different approaches and attitudes towards new knowledge. Teacher candidates who regard themselves as practically oriented may be less willing to accept new educational knowledge or teaching methods than those who are used to reading, working with or conducting research (though not necessarily professionally).

It is worth noting that the degree requirements of the teacher education programmes at the $\mathrm{X}$ University do not actually define PPT. This lack of clarity raises several questions. If these personal and practical theories comprehend everything that a preservice teacher (or qualified teacher) has met in pedagogy during their lives, does it actually say anything specific? Are there any criteria or specifications as to when PPT is acceptable or worthwhile? Should a teacher educator accept whatever PPT their student teacher chooses to present? Lastly, do teacher students and teachers actually enact these personal theories? From the perspective of a young teacher, the gap between daily work and the image given by education may be difficult to deal with. Should a young teacher try to find time for inquiry/research even though merely surviving in front of pupils may be hard? In fact, how can PPT provide support in solving daily challenges? 
We emphasise the need for a better definition of the concepts that form the foundations of Finnish teacher education. Our earlier paper (Säntti et al., 2018) and the results of this article raise the same question: if the fundamental concepts of education are vague, what does this mean in terms of the teacher education system? We see this as particularly important, because for many the education system in Finland is the system to follow or use as an example. If, as we believe despite critical observations, the Finnish education system is exemplary, it is reasonable to clarify why this it so. Highly rhetorical, persuasive, policy-style speech does not fulfil this purpose. We ask if Finnish teacher education should accept the fact that it also has challenges rather than trumpet its success story quite so uncritically. Universally, our results resemble the persuasive aspects of every teacher education system (Heller, 1999). The theoretical parts of education have to be justified and connected to the practice of teaching so well that teacher candidates are convinced of the benefits of theoretical thinking.

\subsection{Limitations and future research}

As previously mentioned, it is difficult to provide an exact interpretation of our data, as some participants reported unfamiliarity with the inquired concepts, most notably PPT. In addition, as we used cluster analysis for the Likert scales measurement method, it is not certain how different participants understood the numerical values presented. Cluster analysis assumes an equal distance between the values and results in studies operating with this measurement method having to be interpreted carefully, as they may not indicate clear-cut differences, but rather potential directions for further inquiries. Further, although our sample was extensive, it was produced in the specific context of teacher education and thus it may not be appropriate to generalise the findings to a larger student teacher population, even in Finland, where teacher education is quite consistent from one university to the next.

The heterogeneity of our data creates some issues with validity and reliability. Students evaluated broad study goals based on many different courses, which might have several teachers during the study year. University teachers in general and at the X University have great freedom to choose materials, methods and evaluation. Thus, courses will always vary at a practical level. In all probability, the students had different abilities to judge factors such as instructor knowledge, course management or the quality of courses In sum, the students clearly understood the meanings of the 
key concepts of education in various ways. Our results may have been different if the concepts of TAR and PPT had been explained in detail in the survey.

All these factors affect how students rated the questions. They also had the third option of 'I cannot say/I do not know' in the questionnaire. They might have avoided making strong evaluations because they were uncertain of what exactly was being evaluated, or because they understood how different their own experiences of the courses were. Of course, this is a dilemma in all studies that quantitatively measure opinions, as well as generally in the educational sciences.

Despite these limitations, our analysis was able to confirm that the TAR and PPT concepts are not realised in teacher candidates' studies as desired. In this respect, our paper complements our earlier historical and rhetorical studies. At the same time, it is obvious that our survey needs improvements to enable more detailed analysis in future studies. Some of the limitations could be solved using a control group that would receive full definitions of TAR and PPT. On the other hand, one could say these concepts are yet to be operationalised. Students may not understand or accept concepts given from above and which have vague meanings.

One possibility for future study is to clarify the main concepts of our study, especially their mutual relationship, which seems to be a rather complex entanglement (Krokfors et al., 2011; Westbury et al., 2005). A potential suggestion to operationalise these concepts more accurately would be to study during teaching practice, for example, how theoretical thinking is developed in practical situations. Possible national discrepancies should also be considered.

One matter concerning our research data remains to be clarified. Our first aim was to gather quantitative data from as many students as possible. We also wanted to give the students the opportunity to express their ideas on education more freely through open-ended questions. After the first quantitative analysis, it became clear that these data were very different. The students were more approving of their studies in the quantitative data than in the open-ended responses. After examining the open-ended question responses, however, we saw that we needed to study the student teachers' views of current teacher education in detail, as these views reflect the diverse and partly conflicting discursive practices through which teacher subjectivities are produced. Thus, our current study indicated a need for further studies to interview students in depth to better understand their possible discontent and criticism as well as their adaptation and assent. As the analysis of the practical course activities was beyond the scope of this research, we call for ethnographies in order 
to gain a better understanding of how educational aims are implemented in courses and how the concept of PPT is introduced and scaffolded.

\subsection{Conclusion}

According to our analysis, the key concepts of Finnish teacher education, Teacher as a Researcher and Personal Practical Theory, are unclear to teacher candidates. The contents, meanings and repercussions of these ideas are either vague or non-existent, which might contribute to disorientation among the students. In the thinking of teacher students, theory is not always connected to practice. Therefore, we emphasise the need to define these concepts to clarify the foundations and aims of Finnish research-based teacher education. We consider this particularly important, as for many, the education system in Finland is a benchmark scheme. 
References

Allen, J. M. (2009). Valuing practice over theory: How beginning teachers re-orient their practice in the transition from the university to the workplace. Teaching and Teacher Education, 25(5), 647654.

Autio, T. (2015). The present educational imaginary in Finland - Only Finnish? Journal of Curriculum and Pedagogy, 3(2), 67-71.

Becher, T., \& Trowler, P. (2001). Academic tribes and territories: Intellectual enquiry and the cultures of disciplines. Buckingham, England: Society for Research into Higher Education \& Open University Press.

Blomberg, S. (2008). Noviisiopettajana peruskoulussa: Aloittelevien opettajien autenttisia kokemuksia ensimmäisestä opettajavuodesta. Helsinki, Finland: University of Helsinki.

Byman, R., Krokfors, L., Toom, A., Maaranen, K., Jyrhämä, R., Kynäslahti, H., \& Kansanen, P. (2009). Educating inquiry-oriented teachers: Students' attitudes and experiences towards researchbased teacher education. Educational Research and Evaluation, 15(1), 79-92.

Darling-Hammond, L. (2010). Teacher education and the American future. Journal of Teacher Education, 61(1-2), 35-47.

Elbaz, F. (1981). The teacher's "practical knowledge": Report of a case study. Curriculum Inquiry, 11(1), 43-71.

Feiman-Nemser, S. (1990). Teacher preparation: Structural and conceptual alternatives. In W. R. Houston (Ed.), Handbook for research on teacher education (pp. 1-61). New York, NY: Macmillan.

Heller, R. (1999). Rhetoric and teacher education. Teaching and Teacher Education, 15(7), $727-$ 740.

Jyrhämä, R., Kynäslahti, H., Krokfors, L., Byman, R., Maaranen, K., Toom, A., \& Kansanen, P. (2008). The appreciation and realisation of research-based teacher education: Finnish students' experiences of teacher education. European Journal of Teacher Education, 31(1), 1-16.

Jyrhämä, R., \& Maaranen, K. (2012). Research-orientation in a teacher's work. In H. Niemi, A. Toom, \& A. Kallioniemi (Eds.), Miracle of education (pp. 97-112). Rotterdam, Netherlands: Sense Publishers.

Kansanen, P. (2014). Teaching as a master's level profession in Finland: Theoretical reflections and practical solution. In O. McNamara, J. Murray, \& M. Jones (Eds.), Workplace learning in teacher education (pp. 279-292). Dordrecht, Netherlands: Springer. 
Kinos J., Saari A., Lindén J., \& Värri V. M. (2015). Onko kasvatustiede aidosti opettajaksi opiskelevien pääaine? Kasvatus, 46(2), 176-182.

Korthagen, F. (2001) Teacher education: A problematic enterprise. In F. Korthagen, J. Kessels, B. Koster, B. Lagerwerf, \& T. Wubbels (Eds.), Linking practice and theory: The pedagogy of realistic teacher education (pp. 1-19). Mahwah, NJ: Lawrence Erlbaum.

Korthagen, F. (2011). Making teacher education relevant for practice: The pedagogy of realistic teacher education. Orbis Scholae, 5(2), 31-50.

Krokfors, L., Kynäslahti, H., Stenberg, K., Toom, A., Maaranen, K., Jyrhämä, R., Byman, R., \& Kansanen. P. (2011). Investigating Finnish teacher educators' views on research-based teacher education. Teaching Education, 22(1), 1-13.

Levin, B., \& He, Y. (2008). Investigating the content and sources of teacher candidates' personal practical theories (PPTS). Journal of Teacher Education, 59(1), 55-68.

Loughran, J. (2006). Developing a pedagogy of teacher education: Understanding teaching and learning about teaching. London, England: Routledge.

Ministry of Education (2007). Opettajankoulutus 2020 [Teacher education 2020]. Helsinki, Finland: Helsinki University Press.

Moore, A. (2004). The good teacher: Dominant discourses in teaching and teacher education. New York, NY: RoutledgeFalmer.

Munthe, E., \& Rogne, M. (2015). Research based teacher education. Teaching and Teacher Education, 46(2015), 17-24.

Niemi, H., \& Tirri, K. (1997). Valmiudet opettajan ammattiin opettajien ja opettajien kouluttajien arvioimina. Tampere, Finland: University of Tampere.

Niemi, H. \& Jakku-Sihvonen, R. (2006). Research-based teacher education. In H. Niemi, \& R. Jakku-Sihvonen (Eds.), Research-based teacher education in Finland-Reflections by Finnish teacher educators (pp. 31-50). Helsinki, Finland: Finnish Educational Research Association. Niemi, H. (2011). Educating students teachers to become high quality professionals - A Finnish case. CEPS Journal, 1(1), 43-66.

Puustinen, M. (2012). Ohjatusta opetuksesta omatoimiseen tutkimukseen - Aineenopettajien kasvatustieteellisten opintojen akatemisoitumiskehitys Helsingin ja Joensuun yliopistoissa 19802011. Kasvatus \& Aika 6 (2), 21-36.

Puustinen, M., Säntti, J., \& Salminen, J. (2015). Ylistystä ja toiminta-alttiutta - retorinen analyysi tutkimusperustaisen opettajuuden rakentamisesta Opettajankoulutus 2020 -loppuraportissa. Kasvatus, 46 (1), 6-18. 
Rantala, J., Salminen, J., Säntti, J., Kemppinen, L., Nikkola, T., Rautiainen, M., \&Virta, A. (2013). Luokanopettajakoulutuksen akatemisoitumiskehitys 1970-luvulta 2010-luvulle. In J. Rantala, \& M. Rautiainen (Eds.), Salonkikelpoiseksi maisterikoulutukseksi: luokanopettaja- ja opintoohjaajakoulutusten akatemisoitumiskehitys 1970-luvulta 2010-luvulle (pp. 61-81). Turku, Finland: The Finnish Educational Research Association.

Rautapuro, J. Tuomisto, V., \& Puhakka, A. (2011). Vastavalmistuneiden opettajien työllistyminen ja akateemisten taitojen tarve. Kasvatus, 42(4), 316-32.

Sahlberg, P. (2011). Paradoxes of educational improvement: The Finnish experience. Scottish Educational Review, 43(1), 3-23.

Simola, H. (2015.) Educational science, the state and teachers. Setting up the corporate regulation of teacher education in Finland. In H. Simola (Ed.), The Finnish education mystery: Historical and social essays on schooling in Finland (pp. 69-94). London, England: Routledge.

Sjølie, E. (2014). The role of theory in teacher education: Reconsidered from a student teacher perspective. Journal of Curriculum Studies, 46(6), 729-750.

Stenberg, K., Karlsson, L., Pitkäniemi, H., \& Maaranen, M. (2014). Beginning student teachers' teacher identities based on their practical theories. European Journal of Teacher Education, 37(2), 204-219.

Stes, A., \& Van Petegem, P. (2014). Profiling approaches to teaching in higher education: A clusteranalytic study. Studies in Higher Education, 39(4), 644-658.

Säntti, J., Rantala, J., Salminen, J., \& Hansen, P. (2014). Bowing to science. Finnish teacher education turns its back on practical schoolwork. Educational Practice and Theory, 36(1), 21-41.

Säntti, J., \& Salminen, J. (2015). Development of teacher education in Finland 1945-2015. Hungarian Educational Research Journal, 5(3), 1-18.

Säntti, J., Puustinen, M., \& Salminen, J. (2018). Theory and practice in Finnish teacher education: a rhetorical analysis of changing values from the 1960s to the present day. Teachers and Teaching, 24(1), 5-21.

Tan, P.-N., Steinbach, M., \& Kumar, V. (2005). Introduction to data mining. Boston, MA: Pearson Addison-Wesley.

Taylor, A. (2008). Developing understanding about learning to teach in a university-schools partnership in England. British Educational Research Journal, 34(1), 63-90.

Tirri, K. (2014). The last 40 years in Finnish teacher education. Journal of Education for Teaching: International Research and Pedagogy, 40(5), 600-609. 
Toom, A., Kynäslahti, H., Krokfors, L., Jyrhämä, R., Byman, R., Stenberg, K., Maaranen, K., \& Kansanen. P. (2010). Experiences of a research-based approach to teacher education: Suggestions for future policies. European Journal of Education, 45(2), 331-344.

Virta, A., Kaartinen, V., \& Eloranta, V. (2001). Oppiaineen vai oppilaiden opettajaksi: aineenopettajan sosialisaatio peruskoulutuksen aikana. Turku, Finland: University of Turku. Vettenranta, J., Välijärvi, J., Ahonen, A., Hautamäki, J., Hiltunen, J., Leino, K., Lähteinen, S., Nissinen, K., Nissinen, V., Puhakka, E., Rautopuro, J., \& Vainikainen, M.-P. (2016). Pisa Ensituloksia. Huipulla pudotuksesta huolimatta. Helsinki, Finland: Ministry of Education and Culture.

Westbury, I., Hansén, S. E., Kansanen, P., \& Björkvist, O. (2005). Teacher education for researchbased practice in expanded roles: Finland's experience. Scandinavian Journal of Educational Research, 49(5), 475-485.

Ylijoki O.-H. (1998). Akateemiset heimokulttuurit ja noviisien sosialisaatio. Tampere, Finland: Vastapaino.

Zeichner, K. M. (1983). Alternative paradigms of teacher education. Journal of Teacher Education, 34(3), 3-8.

Zeichner, K. M., \& Conklin, H. G. (2005). Teacher education programs. In M. Cochran-Smith, \& K. M. Zeichner (Eds.), Studying teacher education (pp. 645-735). London, England: Lawrence Erlbaum Associates. 